\title{
The Effect of Banking Concentration on Non-Performing Loans: The Case of Albania
}

\section{Submitted 12/01/20, $1^{\text {st }}$ revision $17 / 02 / 20,2^{\text {nd }}$ revision $27 / 03 / 20$, accepted $24 / 04 / 20$}

\author{
Arjan Tushaj ${ }^{1}$, Valentina Sinaj ${ }^{2}$
}

\begin{abstract}
:
Purpose: The article examines the correlation among banking concentration and non performing loans using datasets of the Albanian banking sector during 2005-2017. We investigated the non-performing loans affected by market structural variables, banking variables and macroeconomic variables.

Approach/Methodology/Design: We test the loan concentration impact on non-performing loans through linear regression models.

Findings: The Albanian banking sector proved the ambiguous results and the sound correlation in long run among concentration and non-performing loans. Outcome confirmed the negative effect of return on assets and the average interest rate for non-performing loans. Meanwhile the total loans, exchange rates and Gross Domestic Product is affected positively by the non-performing loans.

Practical Implications: The Albanian banking sector operated to moderate concentration despite banks' mergers recently. It has linked with the increasing non-performing loans ratio past to the last quarter of 2008. We demonstrated the empirical impacts that they ought to be taken into consideration by the banking sector.

Originality/Value: The research provides empirical results encouraging further investigations on the subject matter.
\end{abstract}

Keywords: Non-performing loans, concentration ratio, optimum concentration.

JEL classification: L1, C13, E43, E52.

Paper Type: Research case study.

\footnotetext{
${ }^{1}$ Lecturer of Economics, Department of Economics, Faculty of Economics, University of Tirana, Albania,e-mail: arjantushaj@hotmail.com; arjantushaj@feut.edu.al;

${ }^{2}$ Lecturer of Maths and Econometrics, Department of Applied Statistics and Informatics, Faculty of Economics, University of Tirana, Albania, e-mail: sinajv@yahoo.com
} 


\section{Introduction}

The banks' lending remains one crucial determinant linked to economic development, particularly in developing countries to catch up the required growth rates. Meanwhile the lending is associated with certain risk due to the bad loans. That is one additional reason why it should be guarantee the qualitative lending within its return into the banking sector. The lending in banking sector considered theoretic and practical testing particularly at developing countries since the global financial crisis of 2008. The examination persists to investigate the comprehensive background related to lending due to the bad loans by borrowers' default enhancing non-performing loans.

Bonfim (2007) examined determinants related to the lend default converging to correlation among loan hazard and aggregate progress. He confirmed the excessive risk-taking during economic growth due to the strong credit growth. Also he highlighted that the default probabilities linked to numerous particular features of firm, financial indicators, current trade volume or assets' strategies. Abid et al. (2014) examined the variables that they affected the consumers' bad loans in Tunisian banks during 2003-2012 using the dynamic panel data methodology. They investigated the loans' standards related to aggregate and detailed bank indicator. Their outcomes highlighted that the consumers' non-performing loans could clarify through economic aggregate indicators and inappropriate managing.

Tanasković and Jandrić (2015) focused to practical variables affecting the enhance of non - performing loans in countries of Central Eastern Europe and South Eastern Europe from 2006 to 2013. Their results demonstrated a negative impact according to GDP and the positive impact related to loans ratio of overseas coins and swap ratio on non-performing loans ratio. Other authors demonstrated the statistical significance of institutional variables related to NPLs. Curak et al. (2013) applied the dynamic panel method to analyze the determinants related to bad banking credits in South-Eastern European countries. They focused mutually on economical aggregates and specified banking variables and highlighted increasing nonperforming credits due to the fragile macroeconomic circumstances. Meanwhile their results demonstrated that the loans' hazard determined through specified banking characteristics.

Beck et al. (2006) examined theoretic and practical surroundings amongst bank's concentration and solidity comparing to contentious outlooks related to this correlation. They highlighted that the banking concentration might induce mutually stability and fragility in the banking sector.

Jimenez et al. (2007) stress the control's task linked to huge performance limitations and market dominance in order to shrink banks' distress. Their outcomes emphasized the impact of banking running situation and conduct at once related to regulations in the banking sector. 
Albanian banking sector has been involved into a dynamic development. The goal according to their behaviour were achieved by inducing enlarge lending policy. Results of this policy are related to the increasing non-performing loans not only to large loans by banks. These circumstances affected by specific banking determinants, particularly managerial decisions and the macroeconomic developments. Also, these results linked to the performance of core economic sectors. The non-performing loans concentrated by few banks and economic sectors inducing us to examine the relationship between concentration between them.

The article is organized as follows: First section is the introduction. Section 2 provides the theoretical and empirical background related to structural factors according to bad credits. Section 3 demonstrates practical views related to banking concentration jointly with bad credits with reference to banks of Albania. Section 4 analyzes a description linked to econometric methodology and empirical results derived. The final section summarizes the concluding remarks of the article.

\section{Literature Review}

The relation amongst structural and stabilized determinants of the banking sector would carry on contestation and ambiguity through theoretic and practical examinations (Thalassinos and Politis, 2011). These explorations of literature tested the correlation between banking concentration and steadiness in the banking industry. Their outcomes have emphasized the divergence among them through assessments. Several examinations used the non-performing loans as one indicator to measure banking stability to test correlation with banking concentration (Thalassinos and Thalassinos, 2006).

Çifter (2015) investigated the concentration's impact related to bad credits of the banking sector in countries of Central and Eastern Europe. He demonstrated through empirical results on panel dataset the lack of considerable effect of banking concentration related to non-performing loans in short run and long run. According to these results the relationship among them in selected countries was ambiguous using several tested approaches.

Jiménez et al. (2010) examined the correlation amongst banks' concentration and bad credits through Spanish datasets. They found that concentration measures such as $\mathrm{CR}_{5}$ and $\mathrm{HHI}$ related to the loan and deposit market did not affect the nonperforming loans ratios. Their results related to Lerner measures of loan market power demonstrated the negative effect on non-performing loans, but they obtained weak results for deposits. Also they found the negative and especially significant impact on banks' non-performing loan ratios using the common loan and deposit Lerner indexes.

Heimdal and Solberg (2015) analyzed the correlation among banking competition and bad credits ratio in the Norwegian banking sector. They found non-linear 
correlation involving market concentration and loan risk and highlighted that the increased concentration reduces non-performing loan rates until the optimal levels of concentration. Authors found that competition increased the loan risk through the linear positive relationship between competition and bad credits ratio using several competitive measures.

Nilsen et al. (2016) investigated the relationship among non-performing loans ratio and diverse competition's measures using a panel data related to banking sector in Norway. Their results demonstrated U-shaped correlation linking concentration and bad loan ratio. They highlighted that the continuous rising trend of banking concentration provided the higher non-performing loan rates. Chang (2006) analyzed the adjustments of rigid system in Korean banks according to NPLs and BIS ratios. Empirical results highlighted the positive correlation among banks' concentration and bad credits ratio explaining with bad consequences according to banks' control due to the growth of hazardous credits.

Tabak et al. (2007) examined the correlation relating banks' concentration and solidity in Brazilian banks. Their outcomes emphasized the divergence among banking concentration and non-performing loans' ratio. Boyd and De Nicolo (2005) highlighted the affirmative linking amongst banks' concentration and weakness. Their results combined the explanation through banks' power and profits inducing advanced hazard by banks.

\section{Developments of Banks' Concentration and Non-Performing Loans in Albania}

The Albanian banking sector operates into a dynamic development and induces additional controls by banks through their market behaviour. Mutual progress has been affected by the concentration in the banking sector. Figure 1 demonstrates the concentration ratio using $\mathrm{CR}_{3}$ and $\mathrm{CR}_{5}$ related to the banking assets, deposits and loans in the Albanian banking sector during the period of 2008-2017 based on quarterly data. The banking sector was more concentrated due to historical market power of state banks, meanwhile the circumstances of banks' behaviour changed due to new entrances after this period. However recent concentration's tendency justified by improved rank and mergers.

The concentration ratio using Herfindahl-Hirschman Index (HHI) related to the main products in the banking sector is demonstrated in Figure 2. The Albanian banking sector demonstrated the smooth volatility during the period of 2008-2017 based on quarterly data and it demonstrated the moderated concentration related to total assets, deposits and loans denoted the value for each them lower than 0.18. Loans' concentration was low compare to other banking products despite of the upward trend recently. Actually the banking sector operated into the moderated concentration referring to $\mathrm{HHI}$. 
Figure 1. Concentration ratios for the main banking products

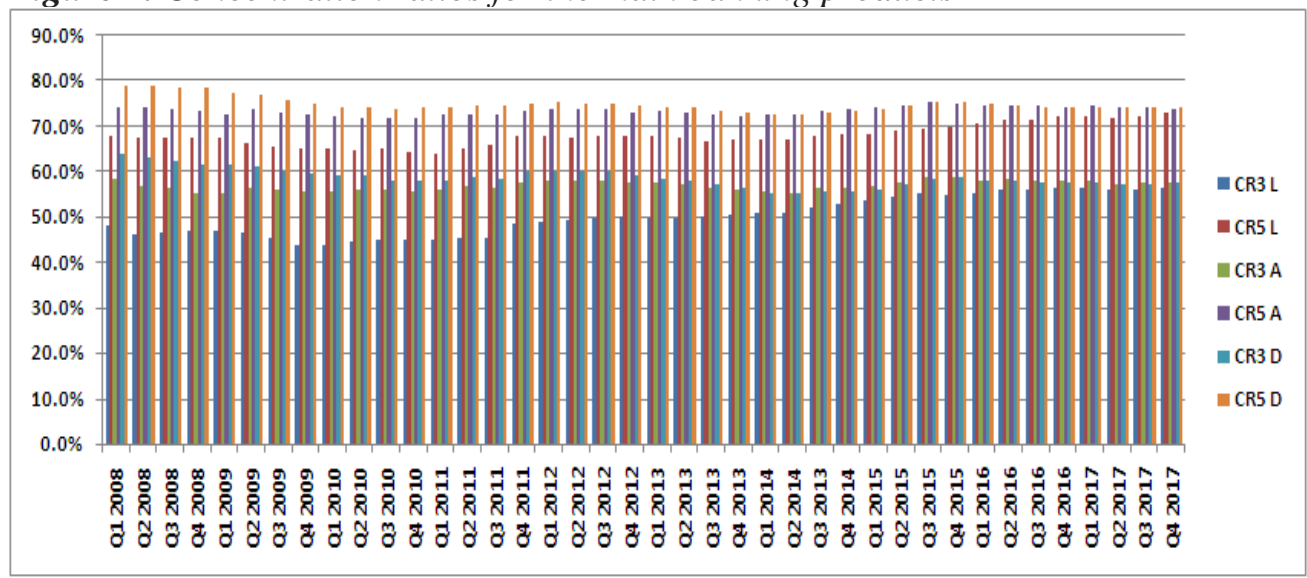

Source: Authors' calculations on dataset of Bank of Albania.

Figure 2. Herfindahl-Hirschman Index for the main banking products

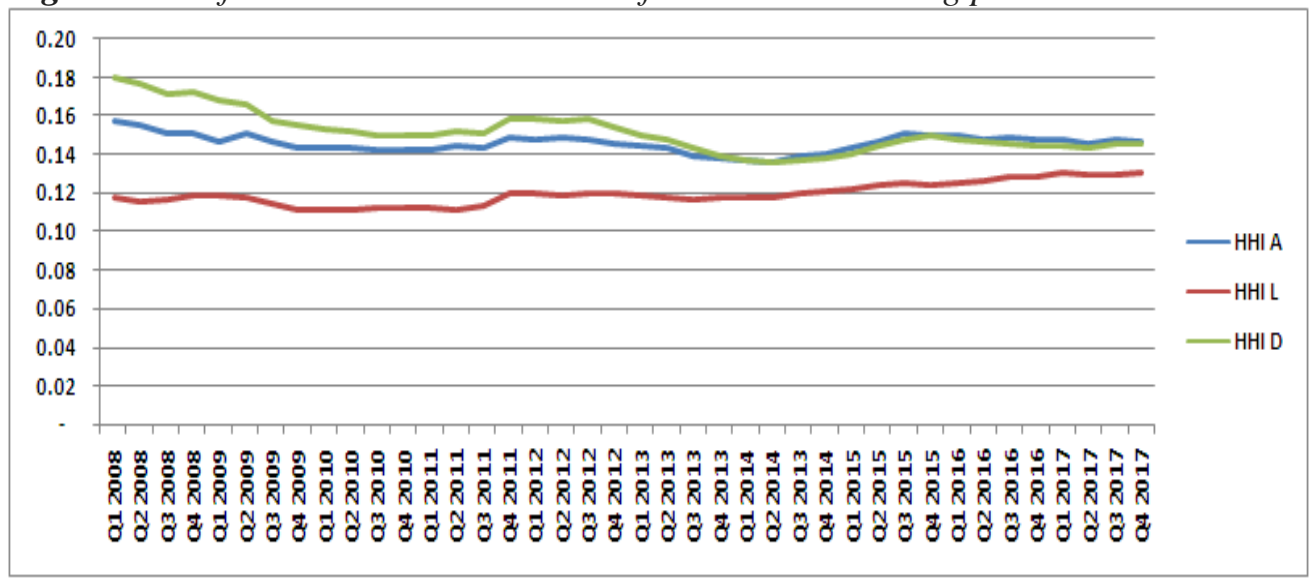

Source: Authors' calculations on dataset of Bank of Albania.

Banks of Albania were sustained their solidity despite sporadic jolts of international financial crisis. Figure 3 demonstrated the dynamics of the growth rate of nonperforming loans and the total gross loans during the period of 2008-2017 based on quarterly data. Referring to this Figure 3 the non-performing loans associated to the volatile trend is dominating by downward tendency. The upward trend during the last quarter of 2008 highlighted the effects of contagious jolts related to worldwide monetary collapse as well as political cycles in Albania.

Meanwhile the downward trend of expansion according to bad credits explained by restrictive banks' lending policy and the intervention of Bank of Albania according to the loans' restructuring although, the smooth trend of loans' growth rate is related to the tight lending policy of banks particularly after 2008 . 
Figure 3. Growth rates of total banks' loan and bad loans in Albania

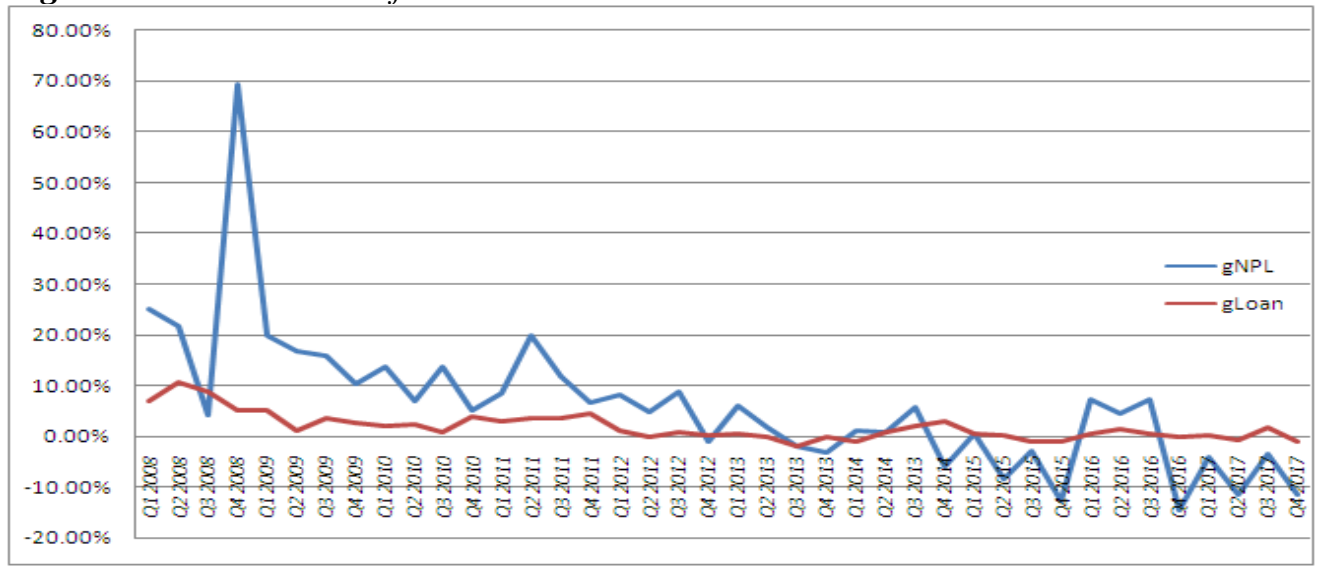

Source: Authors' calculations on dataset of Bank of Albania.

\section{Methodological Background and empirical outcomes}

\subsection{Data Description and Empirical Methodology}

Effect of market structure on the non - performing loans was considered by linear relationship referring on quarterly data according to Albanian banking sector during 2005-2017. The linear model includes the variables controlling for bank sound effects and macro impacts on non-performing loan ratio. The model used the banking concentration according to concentration ratio of loan $\left(\mathrm{CR}_{3}\right)$ such as an indicator of market structural variables. Furthermore we included control variables of bad credits relate through natural logarithm of whole credits, exchange rates (c/ALL) and Gross Domestic Production (GDP). Also we included another control variables related to loan average interest rates and return on assets (ROA). The linear model is the following:

$$
\mathbf{Y}_{\mathbf{t}}=\alpha+\beta \mathbf{X}_{\mathbf{t}}+\gamma \mathbf{X}_{\mathbf{t}}^{2}+\delta \mathbf{Z}_{\mathbf{t}}+\varepsilon_{t}
$$

where $X_{t}$ represents the concentration ratio of loan and $Z_{t}$ represents the control variables. We expect the negative relationship among banking concentration and non-performing loans to be supported by the theoretical view of concentrationstability hypothesis. Also, we used the U-shaped to demonstrate correlation amongst loans' concentration ratio in addition to bad credits supporting by theoretical model (Martinez-Miera and Repullo, 2010). Ambiguous results according to this relationship explained the reversed behavior by optimum concentration. Also we expected the negative impact of ROA (Return on Assets) on bad credits due profitability in addition to positive effects related to loan average interest rates on non-performing loans due to the increasing cost of loans. Return on Assets measures the banking profitability. Our expectation for Return on Assets (ROA) is ambiguous 
due to the positive relationship among risk and return in the long run. Meanwhile, the negative impact of Return on Assets on non-performing loans explaining by reduction in earnings related to high loan losses (Jiménez, Lopez and Saurina, 2013). We expect the negative impact of GDP against the positive effects of exchange rates on non-performing loans due to macroeconomic surroundings and cost of loans and the negative effect of GDP on non-performing loan ratio due to the increasing trend of them during shrinking the economic activities likely decreasing GDP. We also expect the negative impact of total loans and loan average interest rates due to higher risk of additional loans volume and higher cost of borrowing.

\subsection{Empirical Results}

Table 1 verified the statistical significance of different models and their variables. It demonstrates the positive correlation through loans' concentration ratio and bad credits ratio according to linear form. This positive effect explained by banks' behaviour to concentrate the total loans in few large banks and to induce the concentration of non-performing loans by them. Meanwhile empirical results demonstrated the negative relationship among U shape form of loans' concentration and non-performing loans. The negative effect explained by simplistic banking supervision in order to evade bad loans.

These ambiguous results explained the reversed behavior by optimum concentration supporting the theoretical view. Empirical results demonstrated the negative impact of Return on Assets on non-performing loans explaining by reduction in earnings related to high loan losses recently. Also the average loan interest rate confirmed the negative effect due to higher cost of borrowing associated with higher loan risk in spite of statistical insignificancy.

However, the total loans and exchange rates affected positively bad credits ratio explaining by causal correlation among credits' risk and growth of loans' volume in the absence of optimal supervision and exchange rate fluctuations. Meanwhile Table 1 demonstrates the positive effect of the Gross Domestic Product (ln GDP) on non performing loans in spite of statistical insignificancy. This result did not support the theoretical view that the non-performing loans would link doubtless into the fragile macroeconomic surroundings. Positive effect related to the increasing of loans' demand due to the higher incomes for agents linked to growth of GDP. Therefore it would increase the potential risk of bank loans and would contribute to nonperforming loans (Prochniak and Szyszko, 2019).

We tested the series' stationarity by ADF (Augmented Dickey-Fuller test) to demonstrate existence of unit roots. Results related to Table 2 confirmed the existence of unit roots meaning that the series were not stationary using Fisher test, except total gross loan (In Loan), but they were first ranking integrals, except the last series. 
Table 1. Results of estimated models

\begin{tabular}{|c|c|c|c|c|c|c|c|c|c|c|}
\hline Model & [1] & & [2] & & [3] & & [4] & & {$[5]$} & \\
\hline Variable & Coefficient & $p$ & Coefficient & $\bar{p}$ & Coefficient & $p$ & Coefficient & $p$ & Coefficient & $\bar{p}$ \\
\hline $\mathrm{C}$ & -68.32 & 0.00 & -59.14 & 0.000 & -62.23 & 0.000 & -61.36 & 0.000 & -53.31 & 0.000 \\
\hline $\mathrm{CR}_{3}$ & 301.11 & 0.00 & 26.60 & 0.067 & 37.92 & 0.034 & 43.67 & 0.022 & 3.44 & 0.000 \\
\hline $\mathrm{CR}_{3}{ }^{2}$ & -282.81 & 0.00 & -22.93 & 0.011 & -34.69 & 0.054 & 41.54 & 0.033 & & \\
\hline ln Loan & & & 1.28 & 0.000 & 1.16 & 0.000 & 1.18 & 0.000 & 1.34 & 0.000 \\
\hline ROA & & & -0.11 & 0.017 & -0.090 & 0.122 & -0.11 & 0.077 & -0.12 & 0.014 \\
\hline ln ER & & & 9.38 & 0.000 & 8.565 & 0.000 & 8.22 & 0.000 & 9.20 & 0.000 \\
\hline $\ln \mathrm{GDP}$ & & & & & 0.474 & 0.314 & 0.45 & 0.338 & & \\
\hline IR & & & & & & & -0.04 & 0.343 & & \\
\hline $\mathrm{R}^{2}$ & 0.657 & & 0.990 & & 0.990 & & 0.99 & & 0.890 & \\
\hline Adj. $\mathrm{R}^{2}$ & 0.643 & & 0.9896 & & 0.9896 & & 0.99 & & 0.889 & \\
\hline Fisher & 46.917 & 0.00 & 970.14 & 0.00 & 809.24 & 0.000 & 692.50 & 0.000 & 1161.32 & 0.000 \\
\hline $\mathrm{AIC}$ & & 2.454 & & -1.028 & & -1.01 & & -1.00 & -1.003 & \\
\hline $\mathrm{HBC}$ & & 2.56 & & -0.80 & & -0.75 & & -0.7 & -0.81 & \\
\hline HQ & & 2.49 & & -0.94 & & -0.91 & & -0.88 & -0.93 & \\
\hline DW & & 0.241 & & 1.316 & & 1.382 & & 1.44 & 1.81 & \\
\hline Het(Fisher) & & & 2.013 & 0.094 & 1.14 & 0.357 & & & & \\
\hline
\end{tabular}

Source: E-views 7, authors' estimations.

Table 2. Results of series' stationarity

\begin{tabular}{llll}
\hline Variable & \multicolumn{1}{c}{ Stationary } & Coint $p$ & \\
\hline $\ln$ NPL & $\mathrm{F}(4,41)=1.030[0.4033]$ & & $I(1)$ \\
\hline CR $_{3}$ & $\mathrm{~F}(4,41)=0.337[0.8512]$ & $3.23 \mathrm{e}-09 * * * *$ & $I(1)$ \\
$\ln$ ER & $\mathrm{F}(4,41)=2.049[0.1054]$ & $2.95 \mathrm{e}-021 * * * *$ & $I(1)$ \\
$\ln$ Loan & $\mathrm{F}(4,41)=3.304[0.0195]$ & $1.61 \mathrm{e}-030 * * * *$ & $I(0)$ \\
\hline
\end{tabular}

Source: E-views 7, authors' estimations.

We applied the cointegration procedure according to Engel - Granger causality after test of series' stationarity. Table 3 demonstrates the results of coupled variables related to non-performing loans and loans concentration ratio, bad credits ratio in addition to exchange rates according to the significance of model, residuals stationarity and their cointegration. Residuals were stationary referring to " $p$ " value confirming that the series has a steady correlation among non-performing loans and loan concentration and exchange rates in long run.

Table 3. Results of series' cointegration

\begin{tabular}{cccc}
\hline Variable & Model & Stationarity of resids. & $\begin{array}{c}\text { Results of } \\
\text { cointegration }\end{array}$ \\
\hline In NPL \& CR & $3.23 \mathrm{e}_{3}-09^{* * *}$ & $\mathrm{~F}(4,42)=6.4943[0.002]$ & Yes \\
\hline In NPL \& In ER & $2.95 \mathrm{e}-021^{* * *}$ & $\mathrm{~F}(4,42)=5959[0.0029]$ & Yes \\
\hline
\end{tabular}

Source: E-views 7, authors estimations. 


\section{Concluding Remarks}

Empirical data on banking concentration have confirmed concentrated sector related to banks' inheritance according to monopolistic structure. Meanwhile it had converged to moderate concentration referring to HHI despite the upward trend involving the improved banks' ranking and bank's mergers recently. Concentration ratios were correlated to banks consolidated sector.

Banks in Albania have linked to the increasing non-performing loans ratio demonstrating the excessive risk according to banks during the last quarter of 2008 related to contagious effects of worldwide monetary failure and domestic political cycles. However the downward trend of bad credits ratio has been explained by the restrictive banks' lending policy and the intervention of Bank of Albania according to the loans' restructuring.

We investigated the banking distress through the non-performing loans determined by market structural variables, banking variables and macroeconomic variables. Test of loan concentration impact toward the non-performing loans through linear models provided the significant results. These results supported the impact of banks' structure to resolve the non-performing loans problem. The Albanian banking sector proved the ambiguous results among concentration and non-performing loans according to diverse form of relationship. Meanwhile empirical results demonstrated the sound correlation among non-performing loans and loan concentration in long run. Policymakers should be monitoring continuously the banking concentration in the future in order to investigate the optimum credits concentration ratio linking to bad credits.

However the banking in addition to macroeconomic indicators affected nonperforming loans through internal and external shocks. Therefore, it would increase the potential risk of bank loans. Outcome confirmed the negative effect of Return on Assets on non-performing loans due to the earnings' decline of loan losses. Furthermore the average loan interest rate demonstrated the negative effect due to borrowing's costs in spite of statistical insignificancy. Meanwhile the total loans and exchange rates affected positively the non-performing loans due to the potential risk of loans' volume and borrowing's costs of exchange rate fluctuations, respectively. Despite of statistical insignificancy the positive effect of GDP would contribute to non-performing loans rejecting the theoretical view.

\section{References:}

Abid, L., Ouertani, M.N., Zouari-Ghorbel, S. 2014. Macroeconomic and bank-specific determinants of household's non-performing loans in Tunisia: a Dynamic Panel Data. Procedia Economics and Finance, 13, 58-68.

Beck, T., Demirgüç-Kunt, A., Levine, R. 2006. Bank concentration, competition and crises: First results. Journal of Banking and Finance, 30, 1581-1603. 
Bonfim, D. 2007. Credit risk drivers: Evaluating the contribution of firm level information and of macroeconomic dynamics. Working Papers, 7, Banco de Portugal.

Boyd, J., DeNicolo, G., 2005. The theory of bank risk taking revisited. Journal of Finance, 60(3), 1329-1343.

Ćurak, M., Pepur, S., Poposki, K. 2013. Determinants of non-performing loans-evidence from Southeastern European banking systems. Banks and Bank Systems, 8(1).

Chang, Y.T. 2006. Role of Non-Performing Loans (NPLs) and Capital Adequacy in Banking Structure and Competition. Working Paper series.

Çifter, A. 2015. Bank concentration and non-performing loans in Central and Eastern European Countries. Journal of Business Economics and Management, 16(1), 117137.

Heimdal, K.W., Solberg, K.J. 2015. The effect of competition on nonperforming loan rates: Evidence from the Norwegian banking market. Master thesis, MSc in Economics and Business Administration, Norwegian School of Economics Bergen.

Jiménez, G., Lopez, J.A., Saurina, J. 2007. How Does Competition Impact Bank RiskTaking. Federal Reserve Bank of San Francisco, Working Paper Series, 23.

Jiménez, G., Lopez, J., Saurina, J. 2010. How does competition impact on bank risk taking? Banco De Espana, Working Paper, 1005.

Jiménez, G., Lopez, J.A., Saurina, J. 2013. How does competition affect bank risk-taking? Journal of Financial Stability, 9, 185-195.

Martinez-Miera, D., Repullo, R. 2010. Does competition reduce the risk of bank failure? The Review of Financial Studies, 23, 3638-3664.

Próchniak, M., Szyszko, M. 2019. The similarity of European central banks in terms of transparency and effectiveness. Equilibrium. Quarterly Journal of Economics and Economic Policy, 14(3), 385-404. doi: 10.24136/eq.2019.018

Tabak, B.M., Guerra, S.M., Lima, E.J.A., Chang, J.E. 2007. The stability-concentration relationship in the Brazilian banking system. Banco Central do Brasil, Working paper series, 145.

Tanasković, S., Jandrić, M. 2015. Macroeconomic and Institutional Determinants of Nonperforming Loans. Journal of Central Banking Theory and Practice, 1, 47-62.

Thalassinos, I.E., Thalassinos, E.P. 2006. Stock Markets' Integration Analysis. European Research Studies Journal, 9(3-4), 3-14.

Thalassinos, I.E., Politis, D.E. 2011. International Stock Markets: A Co-integration Analysis. European Research Studies Journal, 14(4), 113-129. 